\title{
Stepostectomy as Surgical Correction for Mandibular Prognathism
}

\author{
Takeshi Honda, Ichiro Masui and Katsuma Komoto \\ Second Department of Oral Surgery (Chief : Prof. Katsuma Komoto) \\ Fukuoka Dental College, Fukuoka, Japan \\ Received on 17th May, 1983
}

Surgical correction of the jaw bone has been performed from comparatively old days. Pandya et al. (1971) ${ }^{1)}$ reported that Hullichen first conducted the surgery of the mandibular retraction in 1849 and many surgical techniques as well as the improved methods have been reported since then. ${ }^{2-21}$ ) Since the introduction of Kostecka's method by Nakamura et al. ${ }^{22}$ in 1941 , new methods for the surgery have been introduced one after another in Japan. ${ }^{23-27)}$ The retraction surgery for the mandibular prognathism falls into two broad categories: ostectomy of the body of mandible and ostectomy of the mandibular ramus. At present, the ostectomy of the mandibular ramus, particularly the sagittal splitting method is wildly used. Various surgical methods have been selected and modified by us for the treatment of mandibular prognathism. One of those methods, in which the stepostectomy by Dingman was partly improved, has been used for aboeut 30 cases since 1975, and comporativaly good results have been obtained. The results, chiefly on the surgical mathod, are reported hereafter.

\section{Preoperative Preparation}

Cephalometric roentgenography, conditioned facial photography, and moire ph otography were made preoperatively. The cephalometric analysis was made on the roentgenograms and paper surgery was conducted on the trace of the cephalometric roentgenograms for determination of the amount of the mandible to be retracted (Figs.1 3). Gnathostatic and working models were also produced and while paying close attention to the possible changes of profile and the symmetry by use of the conditioned facial pictures and moire pictures, model operation was performed; determination of the resection line in conformity with the amount of mandible to bo retracted, of the direction of movements of the jaw and mental ridge, and of the occlusal condition (Figs. $4 \sim 6$ ). Occlusal splints were produced from resin on the basis of the occlusal condition newly established (Fig. 7). Lateral and oblique lateral mandibular roentgenograms were obtained for accurate determination of the mandibular canal and mental foramen; they were instrumental for safe determination of the stepostectomy line of the mandible. Examination of the teeth was done by use of roentgenograms, tests for pulp vitality, and the occlusion, and the teath of which 
ROENTGEN CEPHALOMETRIC ANALYSIS (Female Adult)

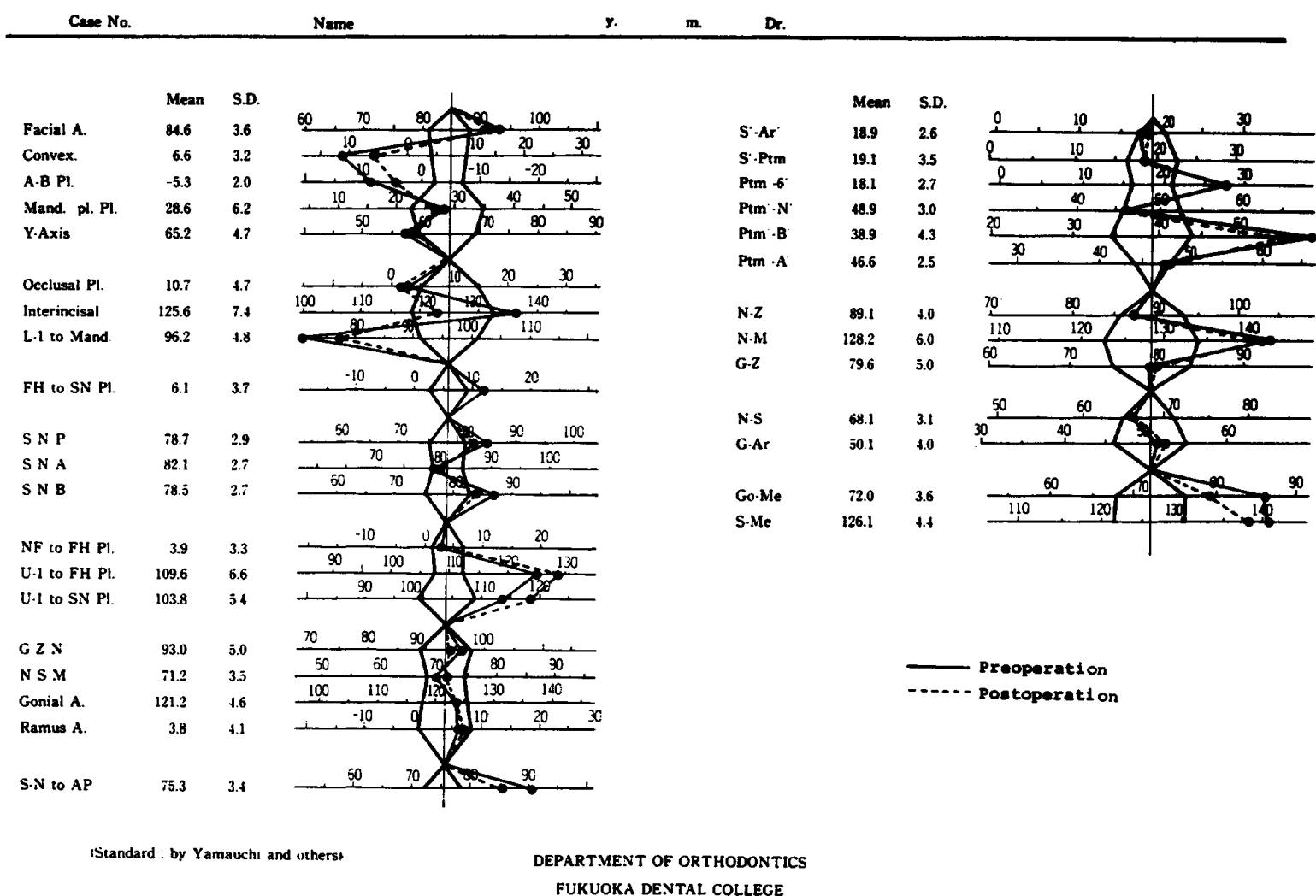

Fig. 1 Comparison of pre- and postoperative roentgen cephalometric analysis.

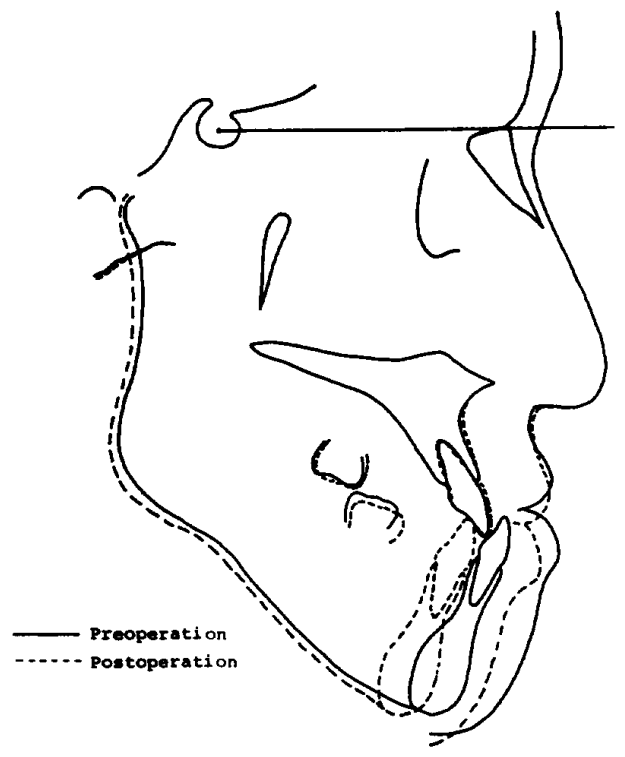

Fig. 2 Superimposed cephalometric tracings of a patient oriented on sella-nasion; postoperative profile compared with preoperative.

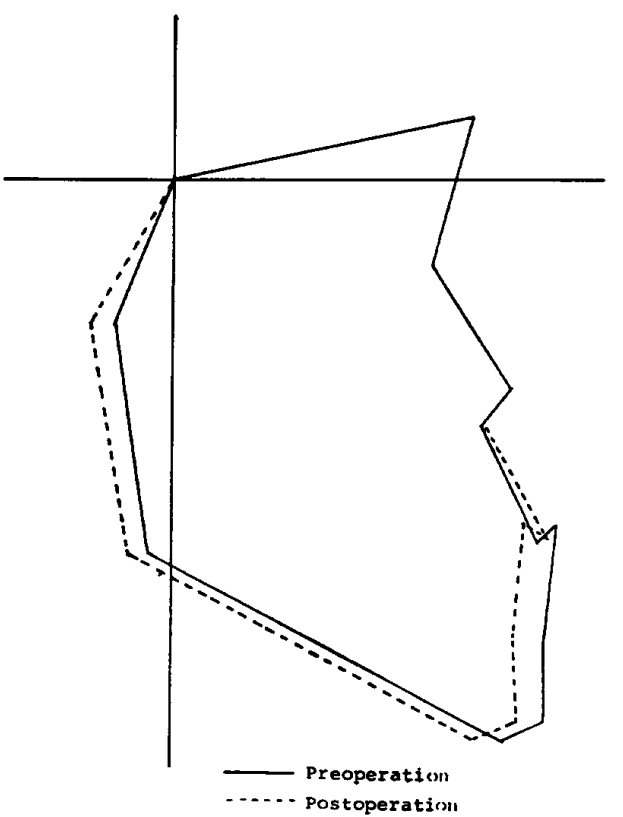

Fig. 3 Superimposed profilograms of a patient oriented on sella-nasion; postoperative profile compared with preoperative. 


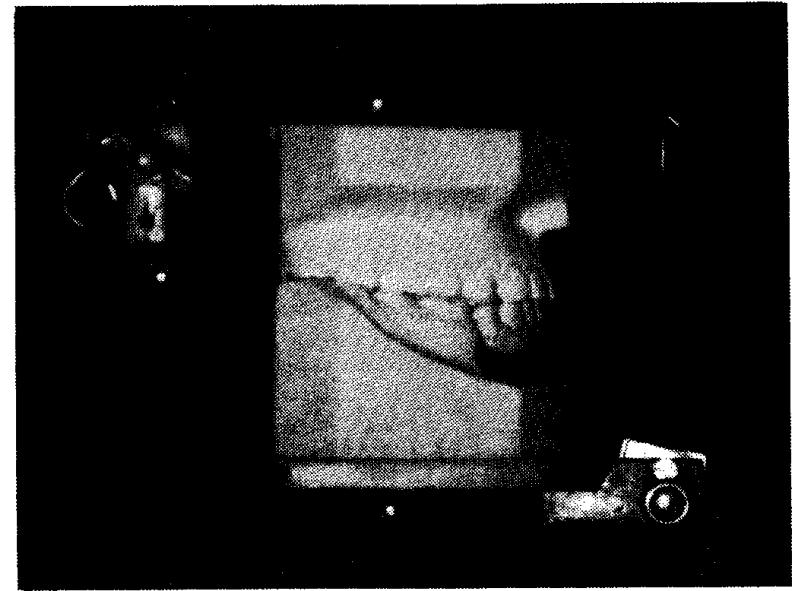

Fig. 4 Model operation on the working model (right side)

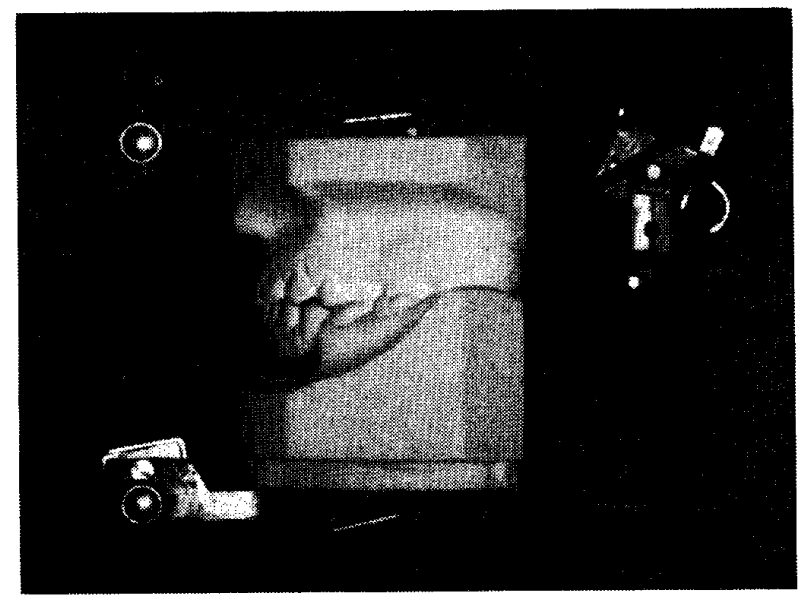

Fig. 6 Model operation on the working model (left side)

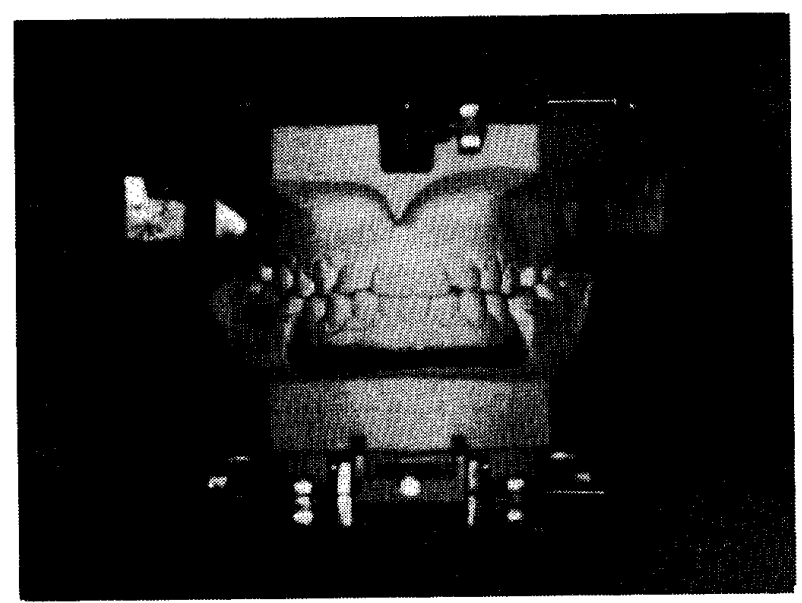

Fig. 5 Model operation on the working model (front side)

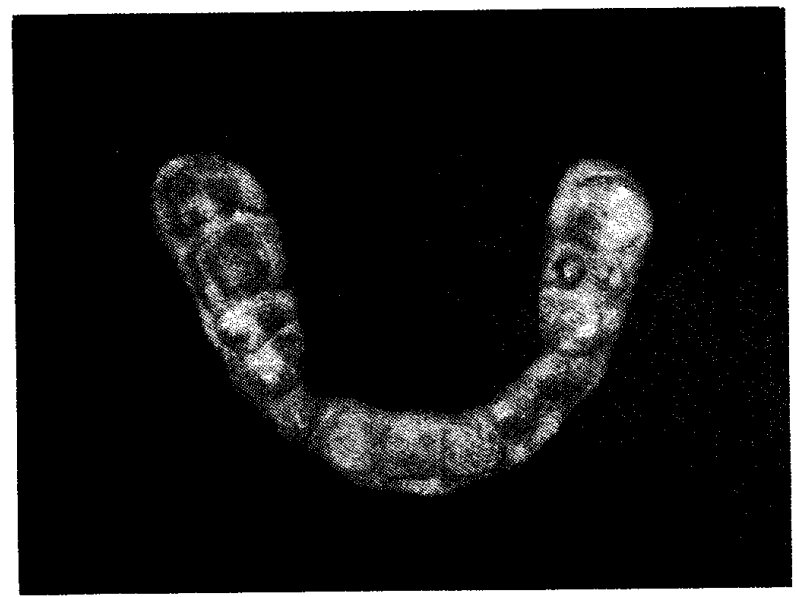

Fig. 7 Ccclusal splint

preservation was difficult were selected after close checking of the amount of the jaw movement.

\section{Surgical method}

Under transnasal, general anesthesia, the mucosa was incised vertically from the cervical line at the distal buccal part of the right and left molar teeth, and the gingiva, together with periosteum, was detached all along the buccal and glossal sides of the teeth to the inferior margin of the mandible (Fig. 8). The muscle and tendon which were connected to the mental spine were preserved and the designated teeth were extracted. The bone resection, which was determined beforehand on the model, was marked accurately on the mandible and the resection was made just as planned on each side. While taking care not to injure the peripheral tissue, ostectomy of the superior margin of the mandible, i.e. the dentoalveolar region, was made by using a bone chisel and surgertome and ostectomy was made in the same manner on 


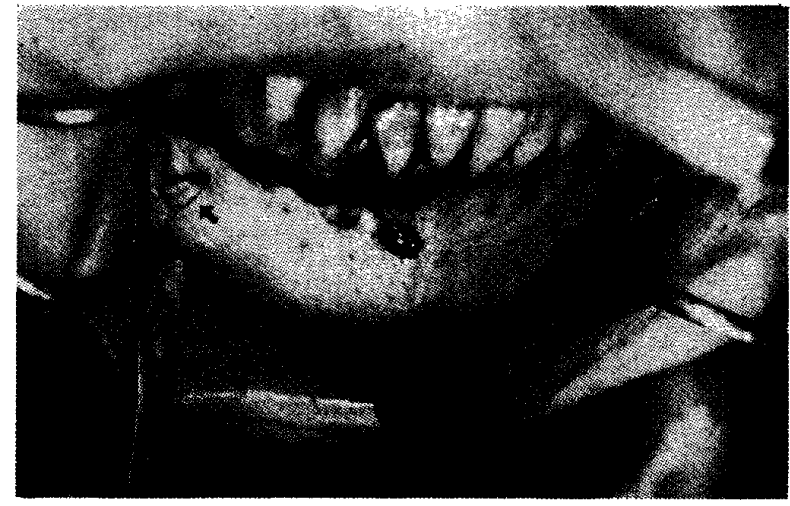

Fig. 8 The gingiva together with periosteum has been detached all along the buccal and glossal sides of the mandible. An arrow points mental nerve.

the inferior margin of the mandible (Figs. 9, 10). On completion of the ostectomy of

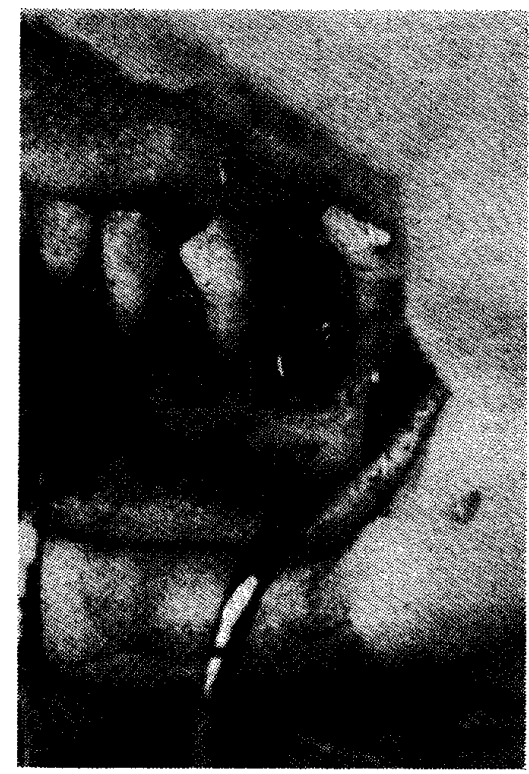

Fig. 9 Ostectomy of the alveolar part has been made. An allow indicates a horizontal cut line.

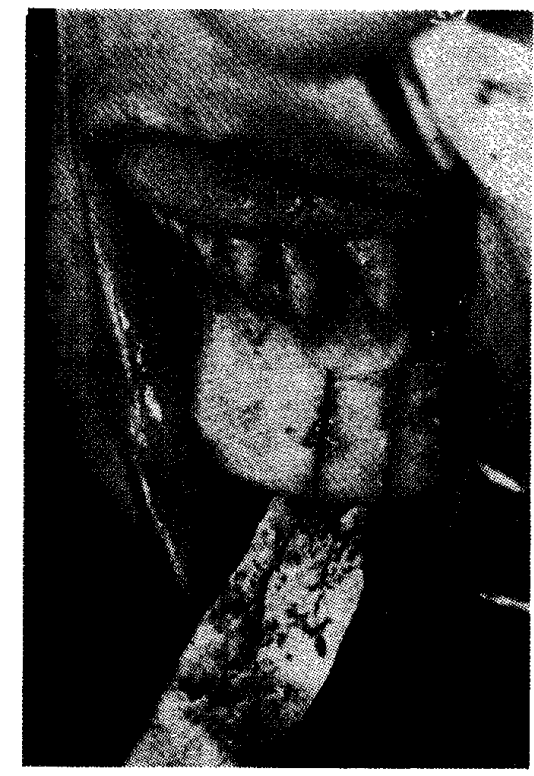

Fig.10 A resectioning line of the lower margin of a mandible.

the superior and inferior margins of the mandible, osteotomy was made horizontally along the line connecting the lower edge of the resected alveolar region and upper edge of the resected lower mandibular margin for separation of the mandible (Fig. 11). In cases where the open bite was found, adjustment of the vertical resection line between the dentoalveolar region and the inferior margin to an appropriate angle was required (Fig. 12). When the stepostectomy on both sides were completed and the mandible was divided into three, the occlusal splint was set before the osteorrhaphy was started; pores were produced by drilling for suturing by use of $\phi 0.6 \mathrm{~mm}$ 


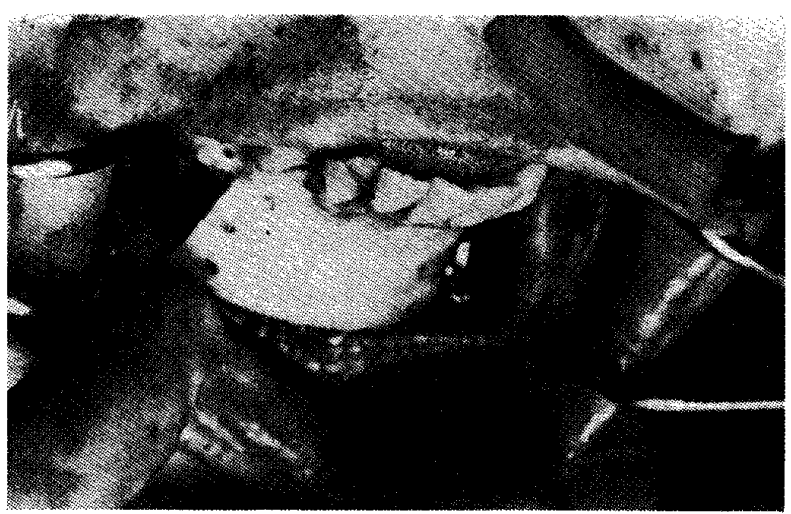

Fig.11 When stepostectomy on both sides has been completed, the mandible is divided into three.
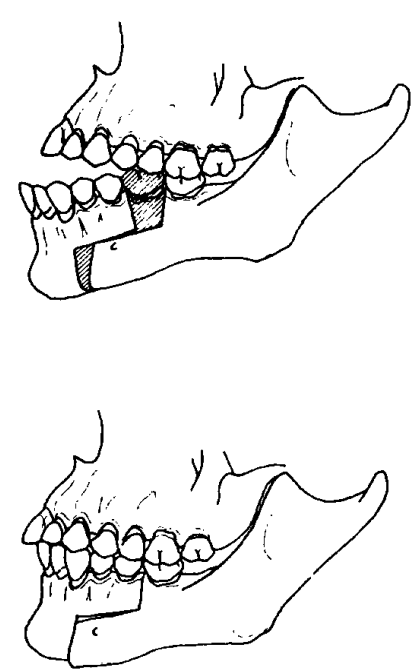

Fig.12 Diagram of stepostectomy for mandiblar prognathism with open bite.

Kirschner wire (Fig. 13). Finally the exposed mandible was covered by gingival mucosa and periosteum, and the stereostatic suture was made. The surgery was

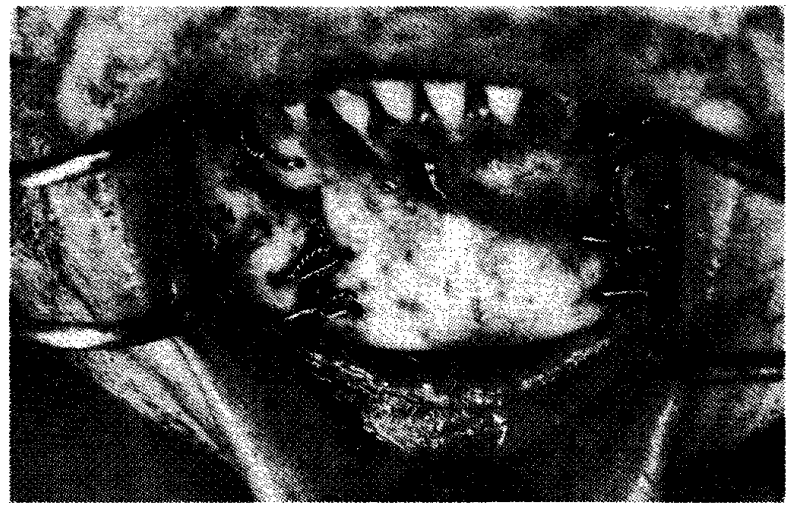

Fig.13 Osteorrhaphy on both sides has been made. An arrow points mental nerve.

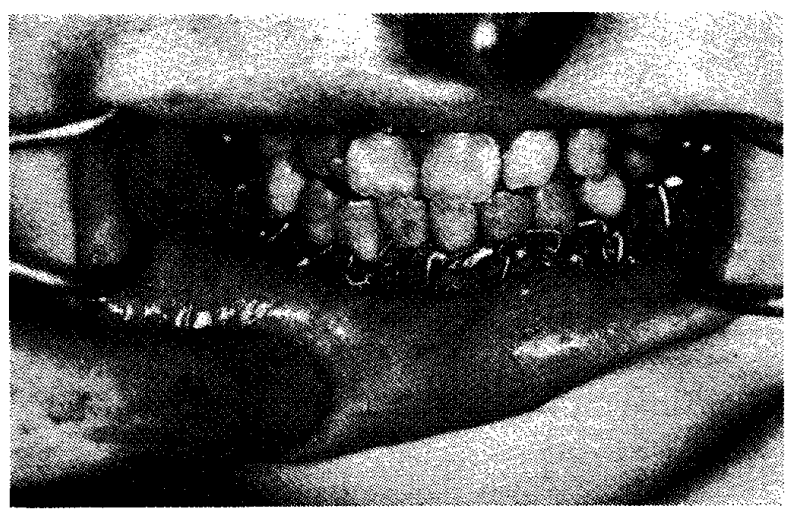

Fig.14 The Sannai Splint has been settled after the stereostatic suture was made. completed by fixing the Sannai splints

(Fig. 14). Intermaxillary fixation was not made till the endotracheal tube was taken out and stable systemic conditions were confirmed (Fig. 15).

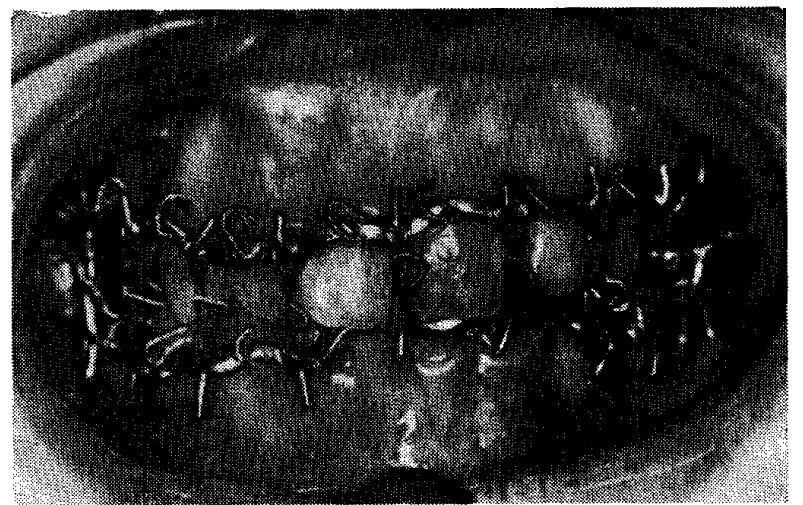

Fig.15 Intermaxillary fixation was made after the confirmation of stable systemic conditions. 


\section{Case Report}

Patient: H.U., a 20year-old female

First visit: July 7, 1980

Chief complaint: Difficulty of speech

Family history and daily life: Nothing in particular

Present illness: Mandibular protrusion was noticed in her junior school days, but no treatment was made. Slight anomaly of speech was perceived one year previously and she visited a dentist, and was introduced to this hospital.

Present symptoms: Slight frontal, facial retraction was observed with the slight inferior growth of the maxilla (Figs. 16,17). In the oral cavity, prominent reverse

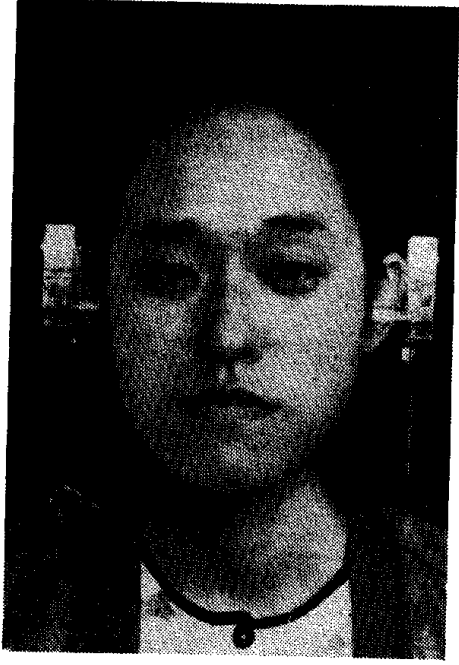

Fig.16 Preoperative photograph (front countenance)

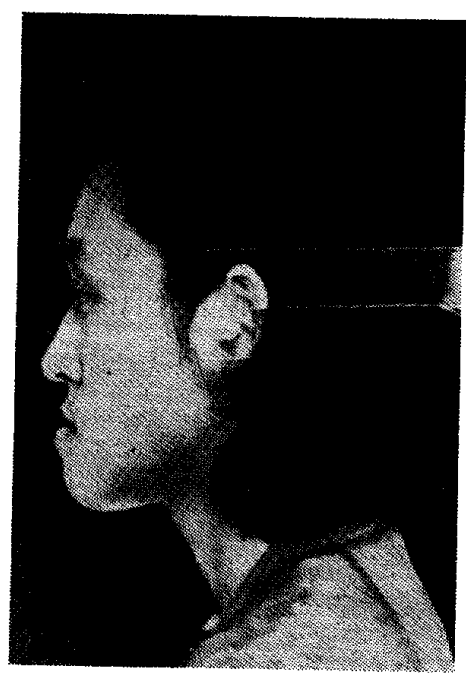

Fig.17 Preoperative photograph (profile)

occlusion was found with overjet at $0.7 \mathrm{~mm}$ and overbite at $0.5 \mathrm{~mm}$. The mandibular second premolars on both sides were dislocated slightly to the glossal direction (Figs. 18 21). Cephalometric roentgenograms showed the overgrowth of ascendens slightly

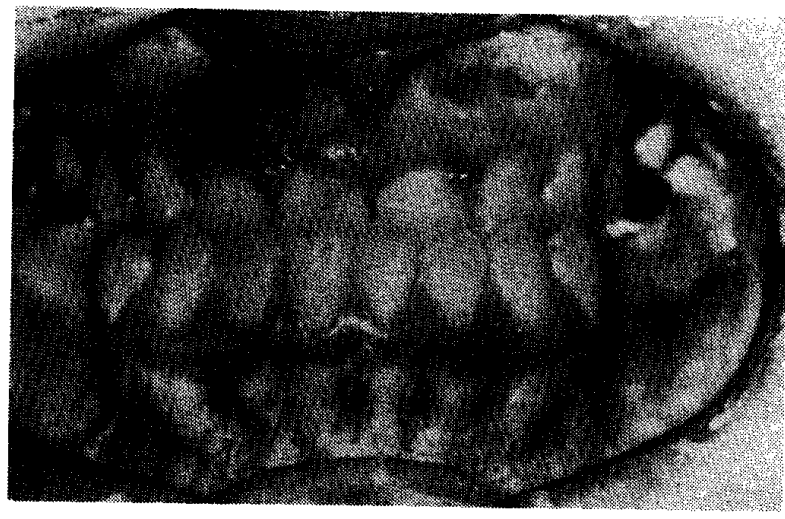

Fig.18 Preoperative intra-oral appearance It shows a remarkable anterior reversed occlusion.

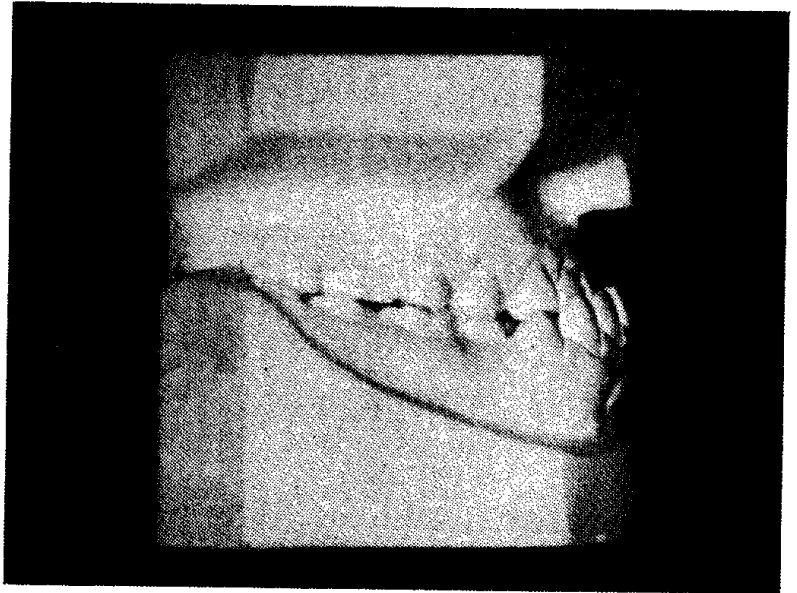

Fig.19 Preoperative gnathostatic model (right side) 


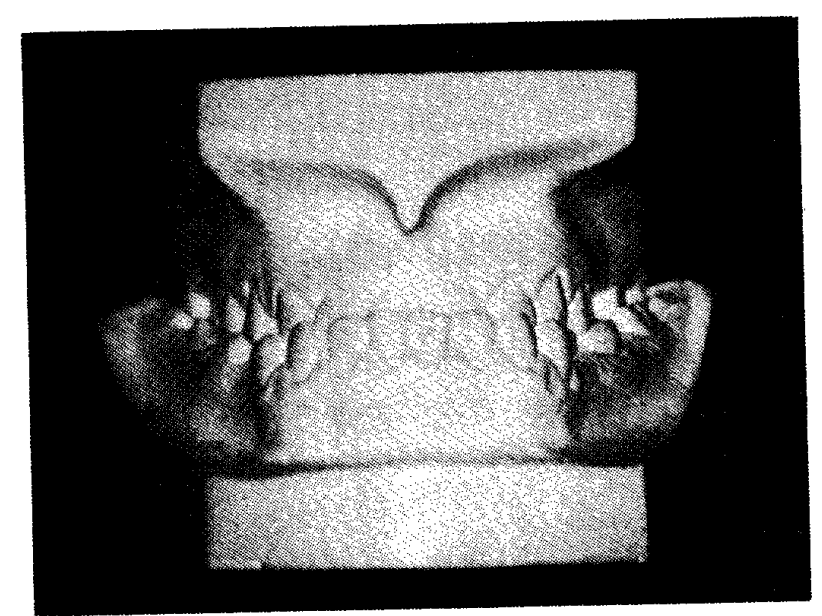

Fig.20 Preoperative gnathostatic model (front view)

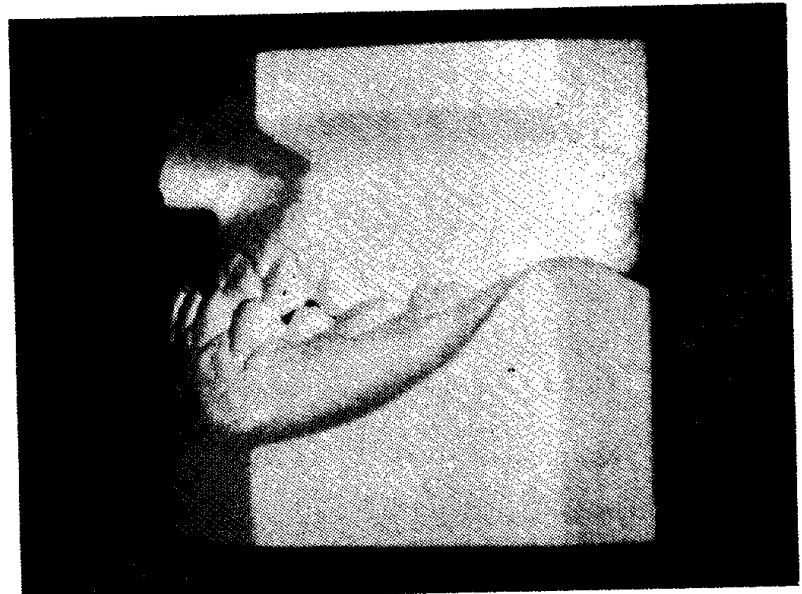

Fig.21 Preoperative gnathostatic model (left side)

to the anterior direction and the body of mandible to anteroinferior direction, presenting a skeletal pattern (Fig. 22).

Surgery: By means of the paper surgery and model operation, the amount of the mandibular retraction was determined at $5 \mathrm{~mm}$, and the stepostectomy, as instructed in the chart, was made after the extraction of the mandibular second premolars on both sides which were dislocated to the glossal direction (Fig. 23). The intraman-

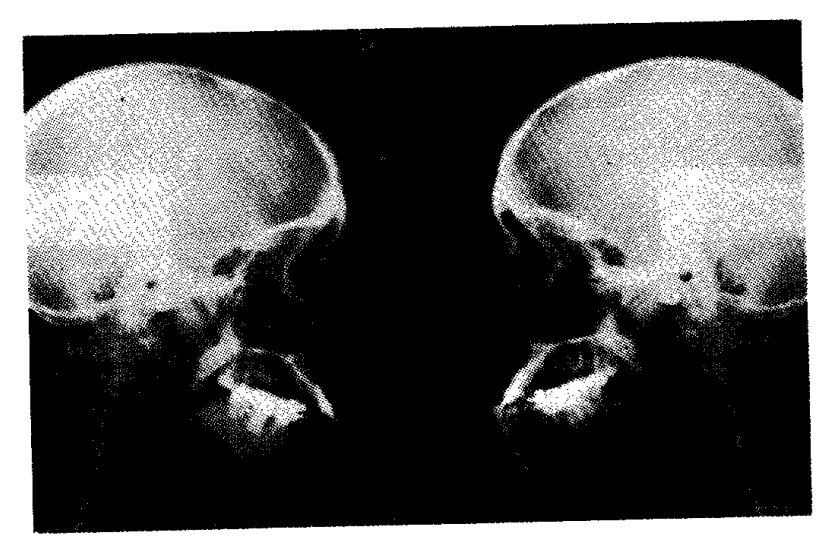

Fig.22 Preoperative lateral cephalograms
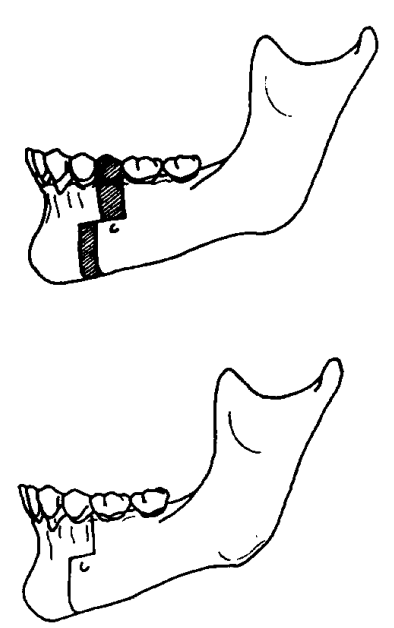

Fig.23 Diagram of the operation method

dibular fixation was made. The fixation was performed for 50 days and the chin retractor was used for about two months after the fixation for prophylaxis of the relapse.

Postoperative findings: The appearance showed significant improvement with retraction of the inferolabial mental region and nearly satisfactory occlusion was obtained (Figs. 24 29). The cephalometric roentgenograms, two years after the surgery, showed almost no relapse (Fig. 30). 


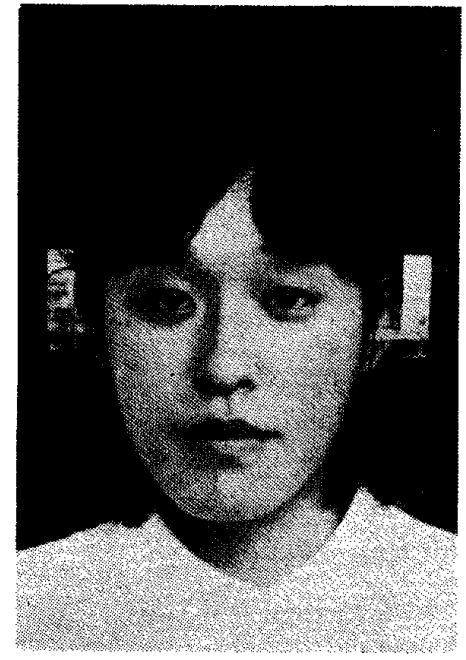

Fig.24 Postoperative photograph (front countenance)

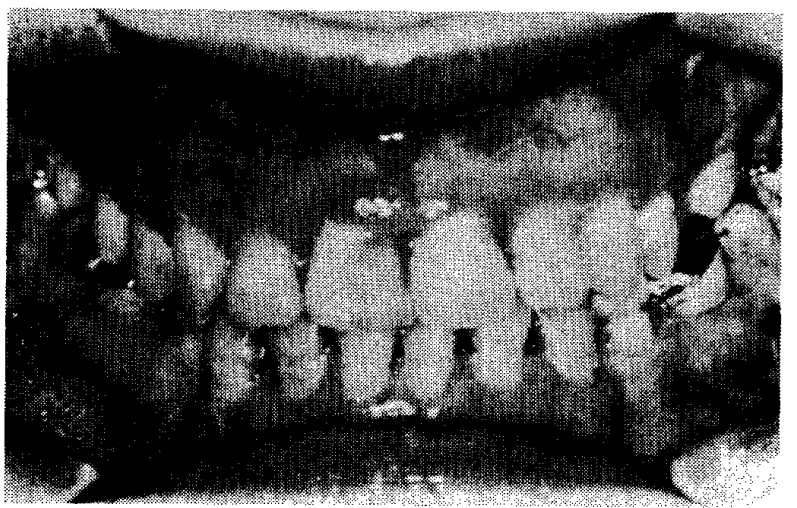

Fig.26 Postoperative intra-oral appearance

It shows a maintenance of good occlusal relationship.

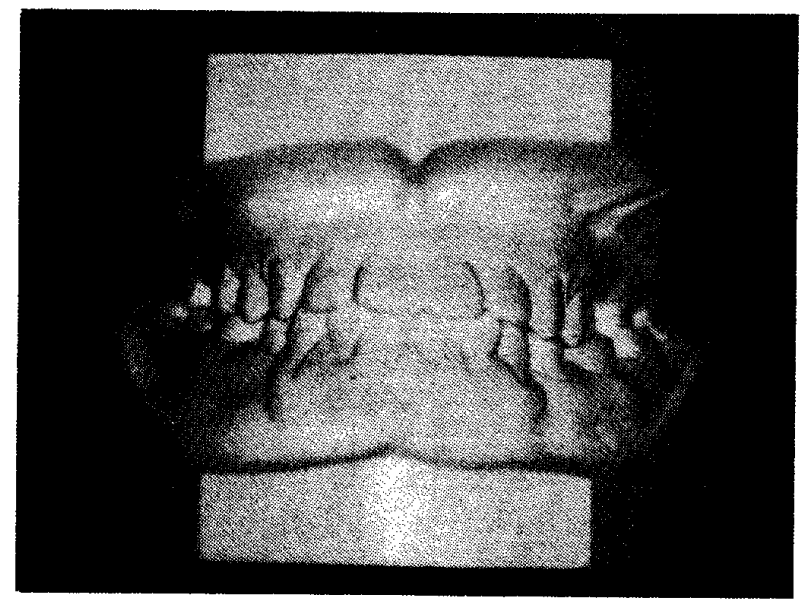

Fig.28 Postoperative gnathostatic model (front view)

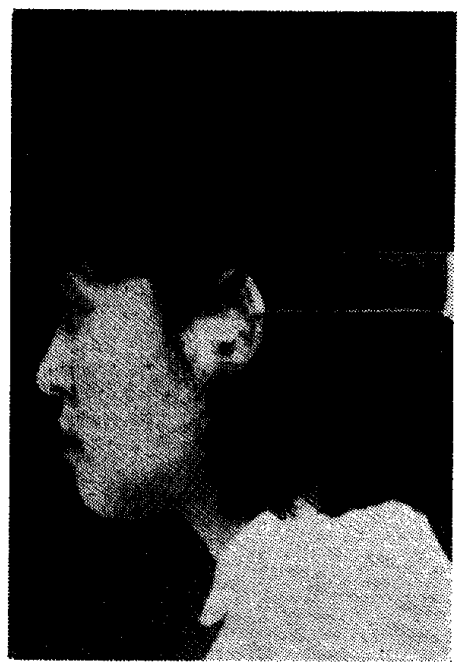

Fig.25 Postoperative photograph (profile)

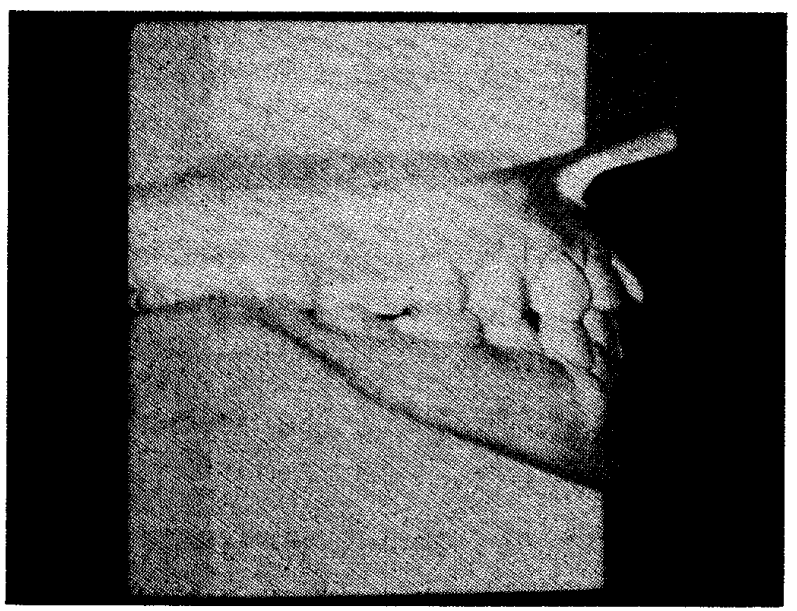

Fig.27 Postoperative gnathostatic model (right side)

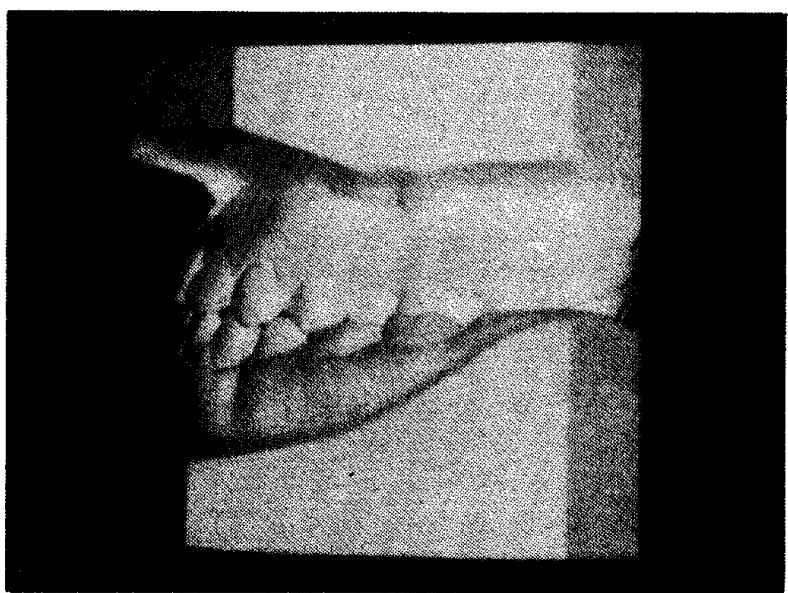

Fig.29 Postoperative gnathostatic model (left side) 


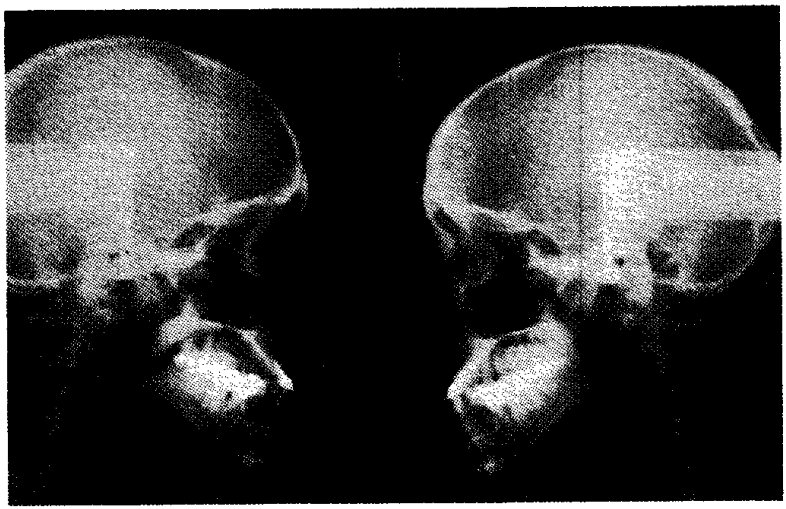

Fig.30 Postoperative lateral cephalograms

\section{Recapitulation}

Since the report of Hullichen ${ }^{1)}$ in 1849 , various surgical techniques and the improvements have been reported as a means of surgical correction for the mandibular protrusion; Blair $(1906)^{3)}$, Babcock $(1909)^{4)}$, Kostécka (1931) ${ }^{6)}$, Schasfer (1941) ${ }^{7)}$, Kazanjian $(1951)^{10)}$, Caldwell et al. $(1954)^{14)}$, Robinson (1958) ${ }^{15)}$, Rowe (1960 $)^{17)}$, DalPont $(1961)^{18)}$, Obwegeser $(1964)^{19)}$, Hinds $(1967)^{20)}$, Quinn et al. $(1970)^{21)}$, Nakamura et al. $(1941)^{22)}$, Kyoyama et al. (1968) ${ }^{24)}$, and Takahashi et al. (1971) ${ }^{26)}$ on the mandibular ramus, Eiselsberg $(1906)^{2)}$, Harsha (1912) ${ }^{5)}$, Dingman (1944) ${ }^{8)}$, $(1948)^{9)}$, Thoma $(1952)^{11)}$, Converse et al. $(1952)^{12)}$, Huebsch $(1954)^{13)}$, Ueno $(1958)^{23)}$, Fukaya et al. $(1971)^{25)}$, and Noma et al. $(1976)^{27)}$ on the body of mandible, and Köle $(1959)^{16}$ ) on the dentoalveolar region. Surgical methods published so far can be generally classified into the resection and retrenchment of the mandibular body, amputation of mandibular ramus, and osteotomy of dentoalveolar region of the mandible (Table 1). Each method, however, has advantages and shortcomings. The

Table 1 Method of operation for progenia

1. Resection of mandibular body

a) Vertical resection of mandibular body

b) Step resection of mandibular body

2. Resection of mandibular ramus

a) Horizontal resection of mandibular ramus

b) Vertical resection of mandibular ramus

c) Oblique resection of mandibular ramus

d) Sagittal resection of mandibular ramus

3. Resection of mandibular alveolar bone

resection and retrenchment of the mandibular body in particular has difficulty in extraction of teeth, injured inferior dentoalveolar region, and narrowed peculiar oral cavity. The past surgery was mostly the extraoral ostectomy of the mandible in which the postoperative scars seem a problem still to be solved. In conducting our 
surgery, special care was taken for the teeth; excluding the cases in which all the teeth were normal, of which preservation was impossible or difficult, such as those unreasonably treated, saprodontia, those with the region of root apex, and broken and loose teeth, were designated for extraction. For protection of the mandibular canal from injury, various studies were made; Dingman (1944) ${ }^{8)}$ and Ueno (1958) ${ }^{23)}$ et al. published the two-divisional, two-staged surgical technique in which the upper and lower dentoalveolar regions were separately incised to avoid the mandibular canal, Fukaya et al. (1971) ${ }^{25}$ ) divided the mandible into the buccal and grossal regions, and Thoma (1952) ${ }^{11)}$ exposed the nerve and blood vessels of the inferior dentoalveolar region. In our studies, the bone resection line was so determined as the region where bone was resected and the mandibular canal did not overlap or cross each other and the surgery was made under intraoral method not to leave scars on the face, and glossectomy, if necessary, was made to cope with the narrowed oral cavity. Our method took 2 hours and 30 minutes on average and the bleeding amount was $200 \mathrm{ml}$ on average. About 55 days were required for the fixation period. Masui et al. $(1983)^{28}$, our colleagues examined the profile of hard tissue by the cephalometric roentgenograms and reported that a few cases of relapse found within about 6 months. Reserch is still under way on the method, etc. of the fixation.

\section{Conclusion}

Since 1975, ostectomy of the body of mandible, particularly stepostectomy of the mandible, in which Dingman's method was partly improved has been performed for mandibular protrusion. Care was taken in the followings:

1. Teeth whose preservation were impossible or difficult were selected for extraction.

2. Determination of the bone resection line in a manner not to make the region where the bone is resected and the mandibular canal duplicate or cross each other for protection of the mandibular canal.

3. Intraoral surgical method not to leave scars on the face. Taking these into account, the stepostectomy of the mandible was done on about 30 cases. Introduced herein are the surgical technique and one of those cases.

\section{References}

1) Pandya, N.J. and Stutevill, O.H. : Vertical wedge ostectomy in the mandibular rami for correction of prognathism. Plast. Reconstr. Surg. $48: 140-141,1971$.

2) Eiselsberg, E. : Über Plastik bei Ektopisem des Unterkiefers. Wien. Klin. Wchnschr. 19:1505 $-1508,1906$.

3) Blair, V.P. : Report of a case of double resection for the correction of protrusion of the mandible. Dent. Cosmos $48: 817-820,1906$.

4) Babcock, W.W. : The surgical treatment of certain deformities of the jaw associated with malocclusion of the teeth. J. Am. Med. Assoc. 53:833-839, 1909. 
5) Harsha, W. : Bilateral section of the jaw for prognathism, report of a case. Surg. Gynec. Obst. 15:51-53, 1912 .

6) Kostećka, F.: Die Chirurgische Therapie der Progenie. Zahnarzte. Rundschu. 40:669-688, 1931.

7 ) Schasfer, J,E, : Correction of malocclusion by surgical interference. Am. J. Orthod. Oral Surg. $27: 172-178,1941$.

8 ) Dingman, R.O. : Ostectomy for the correction of mandibular malrelation of developmental origin. J. Oral Surg. $2: 239-259,1944$.

9) Dingman, R.O. : Surgical correction of developmental deformities of the mandible. Plast. Reconstr. Surg. $3: 124-146,1948$.

10) Kazanjian, V.H. : Treatment of mandibular prognathism with special reference to edentulous patients. Oral Surg. Oral Med. Oral Path. $4: 680-688,1951$.

11) Thoma, K.H. : Oral surgery. 2nd ed., Mosby, St. Louis, 1952, 1495-1497.

12) Converse, T.M. and Shapiro, H.H. : Treatment of developmental malformation of the jaws. Plast. Reconstr. Surg. $10: 473-510,1952$.

13) Huevsch, R.F. : Correction of mandibular prognathism by intraoral ostectomy. J. Oral Surg. $12: 214-219,1954$.

14) Caldwell, J. B. and Letterman G. S. : Vertical ostectomy in mandibular rami. J. Oral Surg. $12: 185-202,1954$.

15) Robinson, M. : Prognathism corrected by open vertical subcondylotomy. J. Oral Surg. 16:215 $-219,1958$.

16) Köle, H. : Surgical operations on the alveolar ridge to correct occlusal abnormalities. Oral Surg. $12: 277-288,1959$.

17) Rowe, N.L. : The aetiology, clinical features, and treatment of mandibular deformity. $\mathrm{Br}$. Den. J. $108: 45-64,1960$.

18) Dalpont, G. : Retromolar ostectomy for the correction of prognathism. J. Oral Surg. 19:4247,1961 .

19) Obwegeser, H. : The indications for surgical correction of mandibular deformity by the sagittal splitting technique. Brit. J. Oral Surg. $1: 157-171,1964$.

20) Hinds, E. C. : Vertical subcondylar osteotomy, A reappraisal. Oral Surg. $24: 164-170,1967$.

21) Quinn, J. H. and Prleans, N : Vertical reciprocating pneumatic saw for mandibular ramus ostectomy. J. Oral Surg. $28: 654-656,1970$.

22) Nakamura, H. and Katoh, K. : Surgical operation for malocclusion and its long term follow-up. Nichiishinpo. $965: 893-895,1941$. (In Japanese)

23) Ueno, T. : Mandibular body ostectomy for prognathism and open bite. Jap. J. P. R. S. 11:52 $-59,1958$. (In Japanese)

24) Kyoyama, T. and Koga, H. : Surgical correction of prognathism by oblique subcondylotomy. J. Kyushu Dent. Soc. 22:174-179, 1968. (In Japanese)

25) Fukaya, M., Takai, Y. and Arai, S : An idea on mandibular body ostectomy in case of prognathism. Japan J. Oral Surg. $17: 295-298,1971$. (In Japanese)

26) Takahashi, S., Shigematsu, T., Ohi, M., Tanabe, H., Ohoka, K. and Ichikawa, T. : Surgical correction of mandibular prognathism by the sagittal ostectomy of ascending ramus. Japan J. Oral Surg. 17:528-538, 1971. (In Japanese)

27) Noma, H., Kakizawa, S. and Kosaka, H.: A surgical correction of the jaw deformity (1). 
The Nippon Dental Review. $404: 21-31,1976 . \quad$ (In Japanese)

28) Masui, I., Nanri, H., Honda, T. and Komoto, K. : Radiographic cephalometric investigation of the stepostectomy correction of mandibular prognathism. J. Fukuoka Dent. Coll. 9 : $497-511,1983$. 


\title{
下顎前突症に対する外科的矯正法としての Stepostectomy
}

\author{
本田 武司・升井一朗・古本 克磨 \\ 福岡歯科大学第 2 口腔外科学講座（主任：教授 古本克磨）
}

下顎前突症に対する下蕷後退術は，一般に下顎骨体部 の ostectomyと下䫇枝の osteotomy に大別され，現在 では下類枝の osteotomy, なかでも矢状分割法が広く 行われている.

私達は 1975年以来，下罘骨体部の ostectomy，特に Dingman 法を一部改良した階段状下顎骨体切除短緮術 (Stepostectomy of the mandible) を行っているが, 他の手術法と比較しても遜色なく， open bite 合併症に 対しても非常に有効で Masui (1983) ${ }^{28)}$ らの報告でも relapse は極めて少なく，非常に秀れた手術法であると 考えられる。
尚，本法を施行するにあたり私達は次の事項に留意し ている。

1）便宜抜去に選定する歯牙は，可及的保存不能また は保存困難柬とする。

2）下䅡管に対する配慮として，骨切除部と下顎管が 重複ないしは交錯しない樣に骨切除線の設定を行う。

3）顔面に手術痕を残さないために，口内法による手 術を行う。

以上，現在私達が行っている下顎前突症に対する外科 的矯正法, 特に stepostectomy of the mandible の手 術々式の概要を報告した。 